SPECIAL ISSUE EDITORIAL

\section{Phylogeography of Neotropical trees}

The Neotropics harbour some of the most species-rich forests in the world, and understanding their biogeographical history has major implications for debates about the origins of tropical diversity (Hoorn et al., 2010; Rull, 2011), for the success of conservation efforts (Faith et al., 2010), and for predicting responses to climate change (Willis et al., 2010). A variety of factors, acting on different time-scales, has shaped these forests and has left imprints in the genetic diversity of the tree species that define them. Phylogeography, the analysis of geographical structure in genetic variation within and among closely related species, provides a framework for relating evolutionary divergence to drivers such as ecological, climatic and geological change. In particular, by combining data from different parts of the genome, the influence of processes acting on different time-scales can be distinguished.

In tackling the evolutionary history of understudied tropical plant species, phylogeography faces many challenges - biological, technical and practical. In some cases species may have poor taxonomic resolution or deep intraspecific genetic divergence, which demands analytical approaches from systematics as well as from population genetics. Widely distributed species may suffer homoplasy at useful loci or - for plants - potentially useful markers (located in the chloroplast genome) may show little or no diversity. Practically, the difficulty of collecting widely across a species' range presents a major obstacle and may require the use of difficult material such as preserved herbarium voucher specimens. Yet the potential for phylogeographical analysis to deliver new insight justifies the effort, and many of the hurdles are now being overcome by technological advances and by collaborative international research efforts. In this Special Issue we present a series of original papers that address these challenges and delve into the genomes of trees to try to answer some longstanding questions in Neotropical biogeography.

Neotropical forests have experienced major change on palaeogeographical (e.g. Neogene and earlier) as well as more recent (e.g. Quaternary) time-scales, but the relative influence of these drivers continues to be actively contested (Hoorn et al., 2010; Rull, 2011). For example, although the formation of much Neotropical diversity was once thought to have been primarily influenced by Pleistocene climatic change, many lowland tree species show Neogene patterns of genetic divergence, suggesting that older forces have played a pervasive role (Dick et al., 2013).

The continental movements that gave rise to the modern Andes and the formation of Central America have been a major driver in Neotropical biogeography. The rising Andes reversed the course of the proto-Amazon river, which had previously flowed westwards (Hoorn et al., 2010), and generated a permanent rain shadow in the western Amazon. Their eroding mineral base enriched the sandy Precambrian soils of the Guiana and Brazilian plates and increased regional edaphic heterogeneity (Fine et al., 2013). The northern Andes are a barrier for rain forest species because of their high elevation, over which most lowland organisms are incapable of dispersing or reproducing (Janzen, 1967), and because the eastern cordilleras intersect with llanos savanna, which is generally too dry to support rain forest vegetation. Despite the enormity of the Andean-llanos barrier, there are a remarkably large number of lowland plant species with a crossAndean disjunction. In the small country of Ecuador, for example, $30 \%$ of the known vascular plants (c. 1438 species) have been collected in lowlands both east and west of the Andes (Jørgensen \& LeónYánez, 1999). It has been suggested that these species were widespread prior to the uplift of the Andes (vicariance hypothesis), which implies a Neogene age and morpho- logical stasis of a large proportion of Neotropical plant species (Raven, 1999).

An alternative view is that the Andes have behaved as a geographical filter, or gatekeeper, for intercontinental species migration. For example, Gentry (1982) noted that Central American forests often harboured the single 'weedy' species of Amazonian tree genera. The characteristics of weedy species, being fast growing, ecological generalists, and able to disperse long distances, would have allowed them to traverse geographical barriers and become established during the climatic fluctuations of the Pleistocene, perhaps when the llanos region was wetter or when coastal corridors were more extensive due to lowered sea levels (Poelchau \& Hamrick, 2013a). In this issue, Cavers et al. (2013), Rymer et al. (2013) and ScottiSaintagne et al. (2013a,b) examine phylogeographical structure in lowland cross-Andean tree species. Of these, Cordia alliodora perfectly fits the Gentry model. This species, which the authors sampled in 25 countries, provides high quality timber yet grows quickly across a range of habitats, including relatively dry forests. Phylogenetic inference supported a South American origin, and although the species shows its greatest genetic divergence across the Andes, shared cross-Andean haplotypes were taken to indicate Quaternary dispersal. Similarly, the prominent 'big-bang' flowering tree Jacaranda copaia showed evidence of Amazonian origins in its pattern of intraspecific genetic and taxonomic variation, with relatively recent dispersal into Central America. In contrast, the Cedrela odorata species complex showed much deeper divergence and cryptic speciation, with a cross-Andean divergence pattern suggesting vicariance or Neogene dispersal.

Because widespread Neotropical tree populations can be so old (Dick et al., 2013), it is possible that contemporary phylogeographical structure developed in landscapes that have since disappeared. Poelchau \& Hamrick (2013a), for example, 
encountered an unexpected phylogeographical structure in two species sampled between El Salvador and Nicaragua - strikingly similar to patterns observed in the same region in Cedrela odorata (Cavers et al., 2003, 2013) - which they suggest may derive from genetic isolation on Tertiary islands that coalesced to form the contiguous landscape of modern Central America. Gugger \& Cavender-Bares (2013), on the other hand, found evidence for a Floridian origin of the Cuban oak, Quercus sagraeana. Oak acorns do not float, suggesting that birds, possibly the extinct passenger pigeon (Ectopistes migratorius), deposited the colonizing seeds during periods of lowered sea level, when the water barrier between Cuba and Florida was reduced.

The effects of Quaternary climate changes on Neotropical rain forest vegetation remain something of a black hole in Neotropical biogeography (but see Pennington et al., 2000). In a novel approach for Neotropical forest trees, Jones et al. (2013) used population genetic data to infer Late Quaternary demographic history of four tree species sampled across the Isthmus of Panama. They found stark differences in population structure between species but, interestingly, the genetic data suggest that all four underwent major demographic shifts (bottlenecks or expansions) during the Late Quaternary, in support of the idea that forests changed in response to climate change. Meanwhile Scotti-Saintagne et al. (2013a) posit Quaternary vegetation change as a driver of regional genetic divergence within Amazon Basin populations of Carapa and Jacaranda copaia. Clearly, the reconstruction of Quaternary vegetation history in the lowland Neotropics will require syntheses of multiple lines of evidence, including palynology, population genetics and palaeoecological niche modelling. Poelchau \& Hamrick (2013b) demonstrate the value of the latter approach through their analysis of Pleistocene forest cover in Central America.

Several of the authors in the Special Issue encountered taxonomic challenges in performing research in species-rich and understudied environments. Herbarium collections in the Amazon Basin, for example, are geographically severely limited (Nelson et al., 1990), which creates problems in delimiting species boundaries. Because of the difficulties of distinguishing some species based on field characters, a 'blind population genetics' approach has been developed (Duminil et al., 2007), wherein species can be segregated based on their assignment to demes. Genetic clustering approaches can also be used to quantify the strength of reproductive barriers and determine levels of hybridization. Cavers et al. (2013) and Scotti-Saintagne et al. (2013a) used these approaches to distinguish cryptic biological species and thereby disentangle genetic structure due to reproductive barriers. In a study focused on incipient speciation, Fine et al. (2013) examined patterns of genetic divergence of populations of Protium located within and among distinct soil types in the Amazon Basin. Their study suggests that edaphic specialization, perhaps in combination with herbivore pressure (Fine et al., 2004), may drive local adaptation and ecological speciation.

The studies have identified some important lessons for future researchers. The importance of taxonomy was clear: several apparent species contained cryptic variation (Cavers et al., 2013; Scotti-Saintagne et al., 2013a) and hence a close interaction between taxonomy and evolutionary biology is vital. The great value of taxonomic collections in herbaria was evident with even very old, preserved samples providing useful molecular data with the possibility for future taxonomic verification. Yet, equally, the importance for phylogeographical studies not to be constrained by taxonomy was apparent: whilst in many cases some markers (such as ITS) mapped onto phylogenies for species or varieties, others were independent, showing patterns of variation more strongly determined by geography than by taxonomic variation, an outcome that has important implications for understanding speciation and morphological evolution in tropical trees. There is a clear need to increase the number of species for which we have rangewide phylogeographical data, and to make use of next-generation sequencing approaches to generate higher resolution datasets. Taking advantage of these studies through comparative analysis will allow us to look more closely at how functional traits and ecology influence phylogeographical patterns and advance efforts to predict how tropical forest might respond to climate change. To this end, building evolutionary responses and important, but neglected, drivers such as soil type into species distribution models would be a major advance.

Finally, the motivation for the SEEDSOURCE project that generated many of the papers in this issue was both academic and applied. In identifying geographical patterns, the research has provided the data for a DNA-based approach to tracking the origins of timber; data that can contribute to global efforts to control illegal logging (Muellner et al., 2011; Degen et al., 2013). Also, by linking data on barriers to gene flow with data from provenance trials, the drivers of evolutionary divergence can be identified, and the boundaries of adaptive units can be defined for better management. By matching locally adapted seed sources to their planting sites, both forestry plantation and forest restoration efforts can ultimately be more successful and scientific studies can return something to the countries in which their efforts have been based.

$$
\begin{array}{r}
\text { Stephen Cavers }{ }^{1 \star} \text { and } \\
\text { Christopher W. Dick }{ }^{2,3}
\end{array}
$$

${ }^{1}$ Centre for Ecology and Hydrology, CEH Edinburgh, Penicuik, Midlothian EH26 $O Q B, U K,{ }^{2}$ Department of Ecology and Evolutionary Biology, University of Michigan Herbarium, University of Michigan, Ann Arbor, MI 48109, USA, ${ }^{3}$ Smithsonian Tropical Research Institute, Gamboa, Republic of Panama E-mail: scav@ceh.ac.uk

\section{REFERENCES}

Cavers, S., Navarro, C. \& Lowe, A.J. (2003) Chloroplast DNA phylogeography reveals colonization history of a Neotropical tree, Cedrela odorata L., in Mesoamerica. Molecular Ecology, 12, 1451-1460.

Cavers, S., Telford, A., Arenal Cruz, F., Pérez Castañeda, A.J., Valencia, R., Navarro, C., Buonamici, A., Lowe, A.J. \& Vendramin, G.G. (2013) Cryptic species and phylogeographical structure in the tree Cedrela odorata L. throughout the Neotropics. Journal of Biogeography, 40, 732-746.

Degen, B., Ward, S.E., Lemes, M.R., Navarro, C., Cavers, S. \& Sebbenn, A.M. (2013) Verifying the geographic origin of mahogany (Swietenia macrophylla King) with DNA-fingerprints. Forensic Science International: Genetics, 7, 55-62.

Dick, C.W., Lewis, S.L., Maslin, M. \& Bermingham, E. (2013) Neogene origins and implied warmth tolerance of Amazon tree species. Ecology and Evolution, 3, 162-169.

Duminil, J., Fineschi, S., Hampe, A., Jordano, P., Salvini, D., Vendramin, G.G. \& Petit, R.J. (2007) Can population genetic 
structure be predicted from life-history traits? The American Naturalist, 169, 662 -672 .

Faith, D.P., Magallon, S., Hendry, A.P., Conti, E., Yahara, T. \& Donoghue, M.J. (2010) Evosystem services: an evolutionary perspective on the links between biodiversity and human well-being. Current Opinion in Environmental Sustainability, 2, 66-74

Fine, P.V.A., Mesones, I. \& Coley, P.D. (2004) Herbivores promote habitat specialization by trees in Amazonian forests. Science, 305, 663-665.

Fine, P.V.A., Zapata, F., Daly, D.C., Mesones, I., Misiewicz, T.M., Cooper, H.F. \& Barbosa, C.E.A. (2013) The importance of environmental heterogeneity and spatial distance in generating phylogeographic structure in edaphic specialist and generalist tree species of Protium (Burseraceae) across the Amazon Basin. Journal of Biogeography, 40, 646-661.

Gentry, A.H. (1982) Neotropical floristic diversity: phytogeographical connections between Central and South America, Pleistocene climatic fluctuations, or an accident of the Andean orogeny? Annals of the Missouri Botanical Garden, 69, 557593.

Gugger, P.F. \& Cavender-Bares, J. (2013) Molecular and morphological support for a Florida origin of the Cuban oak. Journal of Biogeography, 40, 632-645.

Hoorn, C., Wesselingh, F.P., ter Steege, H., Bermudez, M.A., Mora, A., Sevink, J., Sanmartín, I., Sanchez-Meseguer, A., Anderson, C.L., Figueiredo, J.P., Jaramillo, C., Riff, D., Negri, F.R., Hooghiemstra, H., Lundberg, J., Stadler, T., Särkinen, T. \& Antonelli, A. (2010) Amazonia through time: Andean uplift, climate change, landscape evolution, and biodiversity. Science, 330, 927-931.
Janzen, D.H. (1967) Why mountain passes are higher in the tropics. The American Naturalist, 101, 233-249.

Jones, F.A., Cerón-Souza, I., Hardesty, B.D. \& Dick, C.W. (2013) Genetic evidence of Quaternary demographic changes in four rain forest tree species sampled across the Isthmus of Panama. Journal of Biogeography, 40, 720-731.

Jørgensen, P.M. \& León-Yánez, S. (1999) Catalogue of the vascular plants of Ecuador. Missouri Botanical Garden, St. Louis, MO.

Muellner, A.N., Schaefer, H. \& Lahaye, R. (2011) Evaluation of candidate DNA barcoding loci for economically important timber species of the mahogany family (Meliaceae). Molecular Ecology Resources, 11, 450-460.

Nelson, B.W., Ferreira, C., da Silva, M. \& Kawasaki, M.L. (1990) Endemism centres, refugia and botanical collection density in Brazilian Amazonia. Nature, 345, 714-716.

Pennington, R.T., Prado, D.E. \& Pendry, C.A. (2000) Neotropical seasonally dry forests and Quaternary vegetation changes. Journal of Biogeography, 27, 261-273.

Poelchau, M.F. \& Hamrick, J.L. (2013a) Comparative phylogeography of three common Neotropical tree species. Journal of Biogeography, 40, 618-631.

Poelchau, M.F. \& Hamrick, J.L. (2013b) Palaeodistribution modelling does not support disjunct Pleistocene refugia in several Central American plant taxa. Journal of Biogeography, 40, 662-675.

Raven, P.H. (1999) Foreword. Catalogue of the vascular plants of Ecuador (ed. by P.M. Jørgensen and S. León-Yánez), pp. vi-viii. Missouri Botanical Garden, St Louis, MO.
Rull, V. (2011) Neotropical biodiversity: timing and potential drivers. Trends in Ecology and Evolution, 26, 508-513.

Rymer, P.D., Dick, C.W., Vendramin, G.G., Buonamici, A. \& Boshier, D. (2013) Recent phylogeographic structure in a widespread 'weedy' Neotropical tree species, Cordia alliodora (Boraginaceae). Journal of Biogeography, 40, 693-706.

Scotti-Saintagne, C., Dick, C.W., Caron, H., Vendramin, G.G., Guichoux, E., Buonamici, A., Duret, C., Sire, P., Valencia, R., Lemes, M.R., Gribel, R. \& Scotti, I. (2013a) Phylogeography of a species complex of lowland Neotropical rain forest trees (Carapa, Meliaceae). Journal of Biogeography, 40, 676-692.

Scotti-Saintagne, C., Dick, C.W., Caron, H., Vendramin, G.G., Troispoux, V., Sire, P., Casalis, M., Buonamici, A., Valencia, R., Lemes, M.R., Gribel, R. \& Scotti, I. (2013b) Amazon diversification and cross-Andean dispersal of the widespread Neotropical tree species Jacaranda copaia (Bignoniaceae). Journal of Biogeography, 40, 707-719.

Willis, K.J., Bennett, K.D., Bhagwat, S.A. \& Birks, H.J.B. (2010) $4{ }^{\circ} \mathrm{C}$ and beyond: what did this mean for biodiversity in the past? Systematics and Biodiversity, $\mathbf{8}$, 3-9.

This Special Issue was motivated by research undertaken by partners in the SEEDSOURCE consortium (http://www.seed-source.net/), a collaborative project funded by the European Commission under FP6. The project aimed to establish the evolutionary basis and geographical distribution of genetic variation in a range of important Neotropical tree species, for better sourcing and control of germplasm and forest conservation. 